\title{
Annual activity of the lizard Liolaemus occipitalis (Squamata, Liolaemidae) in the coastal sand dunes of southern Brazil ${ }^{1}$
}

\author{
Clóvis S. Bujes² \& Laura Verrastro²
}

1. Contribuição ${ }^{\circ} 465$ Depto. de Zoologia, UFRGS.

2. Setor de Herpetologia, Departamento de Zoologia, Instituto de Biociências, Universidade Federal do Rio Grande do Sul, Av. Bento Gonçalves, 9500, Campus do Vale, Prédio 43435-1, Sala 107, 91501-970 Porto Alegre, RS. (chelonia_rs@hotmail.com, lauraver@ufrgs.br)

\begin{abstract}
The activity pattern of the small sand lizard, Liolaemus occipitalis Boulenger, 1885, was investigated in the coastal sand dunes at Quintão beach (Palmares do Sul, southern, Brazil), between September 1998 and August 1999. The results showed that $L$. occipitalis is active all along the year, but with variations in its daily and seasonal activity patterns associated to climatic changes in the habitat. Lizard activity pattern was distributed as follows: under the sand, burrowed (73\%), under vegetation (14\%), dislocation (7\%) and basking $(6 \%)$. Mean habitat temperatures (air and substrate) were significantly different. The results indicate that L. occipitalis is a thigmothermic and heliothermic species that regulates its body temperature through behavioral mechanisms, and that thermoregulation is mainly associated with substrate.
\end{abstract}

KEYWORDS. Liolaemus, microhabitat use, sand dunes.

RESUMO. Atividade anual do lagarto Liolaemus occipitalis (Squamata, Liolaemidae) nas dunas costeiras do sul do Brasil. Este trabalho teve por objetivo o estudo da atividade anual do lagarto Liolaemus occipitalis Boulenger, 1885. O estudo se desenvolveu nas dunas costeiras da praia de Quintão (Palmares do Sul, sul do Brasil), no período de setembro de 1998 a agosto de 1999. Os resultados demonstraram que L. occipitalis é ativo ao longo de todo o ano com variações diárias e sazonais de acordo com as mudanças climáticas do habitat. A atividade do lagarto se distribuiu da seguinte forma: sob a areia (73\%), sob a vegetação (14\%), deslocando-se (7\%) e exposto ao sol $(6 \%)$. As temperaturas medias do hábitat (ar e substrato) diferiram significativamente. Os resultados indicaram que $L$. occipitalis é tigmotérmico e heliotérmico, regulando a sua temperatura corporal através de mecanismos comportamentais, estando a mesma relacionada principalmente com a temperatura do substrato.

PAVALVRAS-CHAVE. Liolaemus, uso do microhabitat, dunas costeiras.

To keep body temperature within tolerable limits to perform their metabolic functions, lizards behaviourally use the thermal variability of their habitats (i.e., they move alternately from sunny places to shadowy spots); they take stands or attitudes that increase either gain or loss of heat through radiation, conduction and/or by convection; and they either decrease or increase their period of activity in the microhabitat whenever thermal conditions are favorable (HEATH, 1970; GRANT \& Dunham, 1988; Grant, 1990). Since this type of behavioral thermoregulation involves the use of thermal heterogeneity in the habitat, it mays strongly affect on the use of the microhabitat by the lizards (GROVER, 1996).

Microhabitat use by lizards can also be influenced by biotic factors, such as interspecific competition (SCHOENER, 1977; SALZBURG, 1984; NúÑEZ et al., 1989), the avoidance of predators (GibBons \& LilLYwhite, 1981), as well as size and morphology of the individual (MARCELLINI \& MACKEY, 1970; SCHEIBE, 1987). On account of such factors, use of the microhabitat can be determinant. It may have an indirect effect on thermoregulation and it may also have an influence on the evolution of thermal preferences. Therefore, differences in the pattern of temporal activity, in the use of the space, in the foraging pattern, in eating habits, and in the body-temperature relations for the lizards are not independent of each other; on the contrary, they are complex interactions between biotic and abiotic factors (ROUGHGARDEN et al., 1983).
Liolaemus occipitalis Boulenger, 1885, is a small lizard of the family Liolaemidae. Males and females have mean snout-vent lengths of $60.2 \mathrm{~mm}$ and $53.2 \mathrm{~mm}$, respectively (VERRASTRO \& BUJES, 1998). Its geographical distribution is restricted to the sand dunes of the South Atlantic coast of the states of Santa Catarina and Rio Grande do Sul, Brazil. It has a cryptic color pattern, which makes it inconspicuous in the environment background. The minimum reproductive size is $50 \mathrm{~mm}$ for males, and $45 \mathrm{~mm}$ for females (Verrastro \& Krause, 1994). Reproduction takes place between September and March. The species is chiefly insectivorous and it is active during day time (Verrastro \& Krause, 1994). Its main defense strategy against predators is burrowing superficially in the sand or escaping into refuges. The most commonly observed thermoregulating behavior of $L$. occipitalis is moving between sunlight exposed sites to shaded sites amidst dense vegetation (VERRASTRO \& BuJEs, 1998).

One population of Liolaemus occipitalis of the state of Rio Grande do Sul, was the object of investigation for the present study, which aims to determine the annual activity pattern of the species, as well as its seasonal rhythm of activity in its environment.

\section{MATERIAL AND METHODS}

This study took place in an area of approximately $40,000 \mathrm{~m}^{2}$ in the sand dunes of Quintão beach, in the 
municipality of Palmares do Sul, southern Brazil (30 24'S; $\left.50^{\circ} 17^{\prime} \mathrm{W}\right)$. This area was chosen because it had a high population density of lizards. It is situated $4 \mathrm{~km}$ from Lagoa do Quintão and $3 \mathrm{~km}$ from the Atlantic Ocean, in the coastal plain, being a flat landscape with walking sand dunes on holocenic geological substrate (Delaney, 1965). The soil is formed by non-fixed sand-quartz deposits of eolic accumulation and quaternary origin (PORTO \& Cortazzi, 1982). The climate is of the type Cfa (Köppen classification) with mean annual rainfall around $1,323 \mathrm{~mm}$ and no characteristic dry season. The mean annual air temperature is $20^{\circ} \mathrm{C}$. Northeastern winds predominate during the year (EIDT, 1968).

The coastal vegetation in the vicinity of the study site is described in Pfadenhauer \& Ramos (1979), Pfadenhauer (1980), and Waechter $(1985,1990)$. The vegetation in the study area is sparse, with plants covering less than 5\%, and consists exclusively of herbaceous, psammophilous species, mainly Poaceae. The habitat includes small hummocks and dunes of sand 20 to $50 \mathrm{~cm}$ high, many of which are situated next to clumps of herbaceous plants. In depressed areas among the dunes, temporary flooding may occur because of heavy rainfall. When these depressed areas accumulate organic matter for a long time, they become covered by dense, perennial plant species. The most abundant species is Panicum racemosum (Poaceae), which forms almost homogeneous clusters in wide extensions on top of small elevations. In the lower elevations, other Gramineae occur.

Observations were done monthly from September 1998 to August 1999, with whole area being visited within two days, between 08:00 and 18:00. Notes were taken for field records, and every activity of the lizard was described at the moment when it was first seen. After that, the lizard was manually captured, its snout-vent length (SVL) was measured $(\mathrm{mm})$ and the lizard was weighed $(\mathrm{g})(\mathrm{BM})$. With these two values, three age groups were established: young specimens (undetermined sex); immatures (SVL up to $45 \mathrm{~mm}$ for females, and up to $50 \mathrm{~mm}$ for males); and, adults (SVL higher than $45.1 \mathrm{~mm}$, for females, and higher than $50.1 \mathrm{~mm}$ for males). Behavioral patterns were adapted from VerRastro \& Bujes (1998), and these were: "under sand," "under vegetation," "basking," and "dislocation". Moreover, air temperatures $\left(\right.$ in $^{\circ} \mathrm{C}$ ) were taken (at $10 \mathrm{~mm}$ from ground surface), as well as temperatures of the substratum and at $50 \mathrm{~mm}$ and $100 \mathrm{~mm}$ below substratum using contact thermometers. Results were arranged according to frequency of sightings and divided in: (1) sightings per season of the year; (2) activities per season of the year; (3) age groups per season of the year; (4) age groups per activity per season of the year. Seasons of the year were established as follows: spring (from September to November, 1998), summer (from December, 1998 to February, 1999), fall (from March to May, 1999), and winter (from June to August, 1999). Temperature curves of the microhabitat were drawn from the averages of the monthly recorded temperatures.

\section{RESULTS AND DISCUSSION}

The specimens captured had a mean SVL of 50.31 $\mathrm{SD} \pm 9.83 \mathrm{~mm}(\mathrm{~N}=301)$, with a mean $\mathrm{BM}$ of $4.92 \mathrm{SD} \pm 2.62 \mathrm{~g}$.

The rhythm of activity of $L$. occipitalis varied throughout the year (Fig. 1), usually showing a tendency
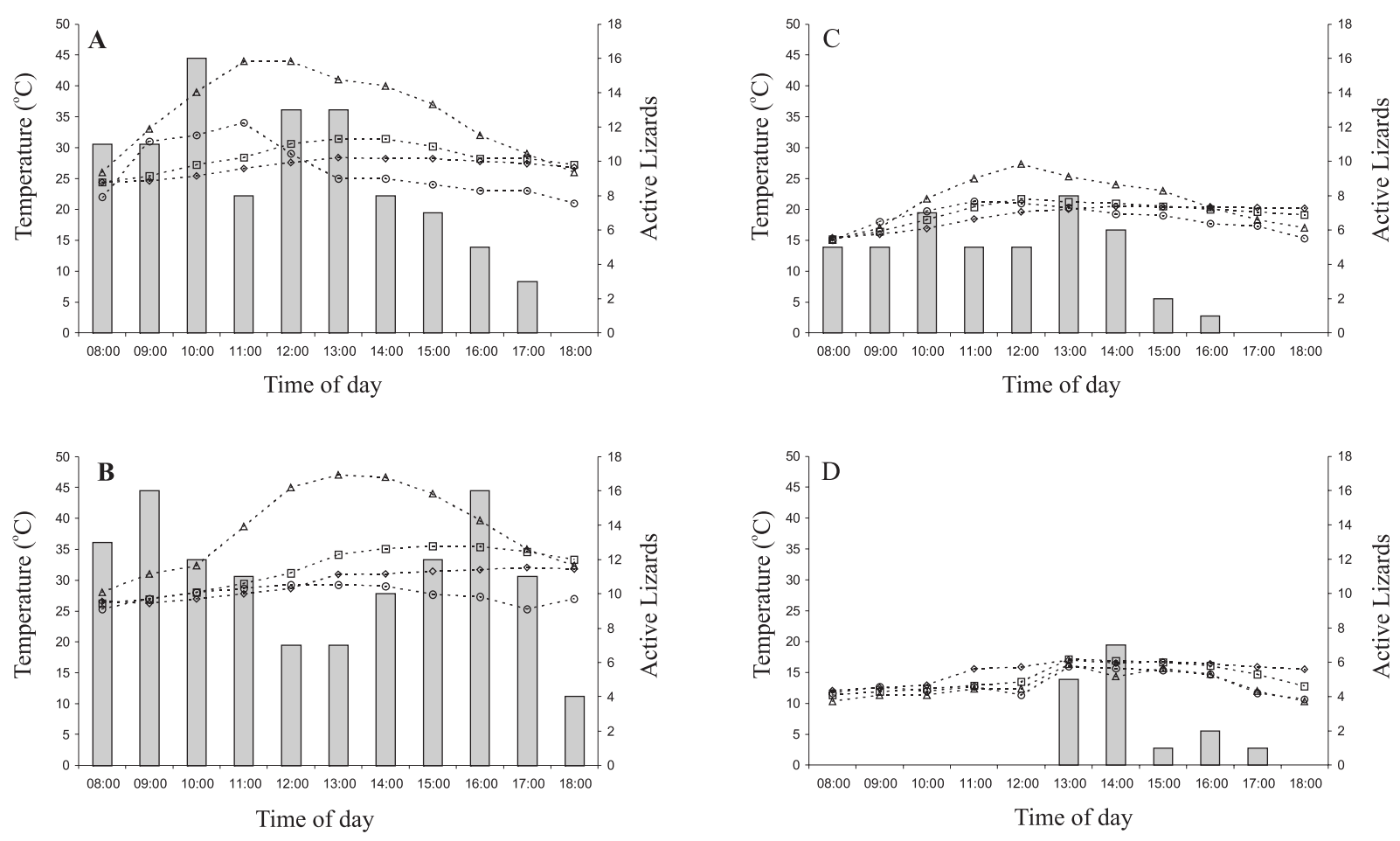

Fig. 1. Diel changes in mean microhabitat temperature: air temperature (circles), soil temperature at surface (triangles), $50 \mathrm{~mm}$ (square), and $100 \mathrm{~mm}$ of depth (lozenge); and daily activity cycle of Liolaemus occipitalis Boulenger, 1885 in the sand dunes of Quintão beach, Palmares do Sul, southern Brazil, recorded in Spring (A), Summer (B), Fall (C), and Winter (D) between September 1998 and August 1999. 
toward a bimodal rhythm. The same behavior was found in several species from Chile, such as L. curis Núñez \& Lobra, 1985 (NúÑEZ, 1996), L. fuscus Boulenger, 1885 and L. lemniscatus Gravenhorst, 1837 (NúÑEZ et al., 1989). NúÑEZ (1996) argues that the predators pressure on lizards is a determining factor for the activity of the preyedupon organisms, and mentions the example of L. hermani Sallaberry \& Nunez, 1982, a lizard with a unimodal activity restricted to the morning period, whereas its predators prefer to be active in the afternoon. Thus, the species would be responding to the pressure of its predators with morning activities. It was also observed a unimodal activity pattern in L. lutzae (Mertens, 1938) from the restingas in Rio de Janeiro a pattern that was mainly concentrated in the morning (RochA, 1988). On the other hand, RocHA (1991) asserts that the pattern of coloration of the L. lutzae, rather cryptic on the sands of the shore, added to the fact that open areas in general offer more opportunities to predation, suggests that the pressure of predators in the area must be high, and predators in general use vision to locate lizards. Given that $L$. occipitalis also presents cryptic coloration (VERRASTRO, 2004) as a response to the environment and that it is active throughout the day in spite of suffering the pressure of predators such as the bird Guira guira Gmelin, 1788 and the snake Lystrophis dorbignyi (Duméril, Bibron \& Duméril, 1854) (C. S. Bujes pers. obs.), one can conclude that most probably the activities of $L$. occipitalis are directly related to the interaction of these factors with its thermoregulation, as well as to its sitand-wait type of foraging (PIANKA, 1977).

L. occipitalis was active throughout the year. The lizards kept themselves active from 7:30-8:00a.m. to 6:00$6: 30$ p.m., during the spring and summer. Two peaks of activities were observed during spring: the first, between 8:00 and 10:00a.m., and the second, between 12:00 and 3:00p.m. During summer, the peaks of higher activity were registered between 8:00 and 10:00a.m. and between 2:00 and 5:00p.m. During both seasons those peaks diminished during the hours of higher temperatures. Activity diminished perceptibly during fall and winter. During winter, active lizards could only be seen after 1:00p.m. The largest range in numbers of active lizards was observed during spring (a minimum of 3 and a maximum of 16 individuals) and during summer (a minimum of 7 and a maximum of 16). During the study, mean habitat temperatures (air and substrate) were significantly different among seasons (ANOVA, $\mathrm{F}_{3857}=81.64 ; \mathrm{P}<0.001$ ).

The activity of $L$. occipitalis throughout the year seems to be associated to thermoregulation. Most of the lizards sighted $(73 \%)$ were under sand. The main thermoregulating and evading behavior of the $L$. occipitalis is to dive into the sand (VERRASTRO \& BUJES, 1998). This will allow the lizard, during most of its period of activity, to keep temperatures relatively lower than those registered when exposed directly to sunlight. In the study performed by BuJEs \& VerRAstro (2006), an ecritic temperature of approximatelly $31^{\circ} \mathrm{C}$ was observed for this species and was significantly differnt from the recorded mean annual air temperature $\left(25.74^{\circ} \mathrm{C}\right)$. It is also a strategy to avoid the risk of predation when it is in an open area. It also avoids the constant heat loss that would be expected with a prolonged exposure to colder air temperatures caused by a exposure to the constant wind which is characteristic of the coastal region. FUENTES \& JAKSIC (1979) documented this fact in species of Liolaemus from Chile. All three species from the coastal region presented ecritic temperatures lower than continent species due to the heat loss by wind exposure. The burrowing behavior is observed in all species in the group boulengeri, to which L.occipitalis belongs, with exception of L. ornatus Koslowsky, 1898 (Halloy et al. 1998). According to a study performed by HALLOY et al. (1998), this innate behavior would be the main sinapormorphy of the species in the group boulengeri, suggesting a phylogenetic component.

The activity of $L$. occipitalis throughout the year showed the following distribution: $73 \%$ of the lizards were found under sand, $14 \%$ were under vegetation, $7 \%$ were dislocating, and 6\% were in basking (Fig. 2). The fact that $14 \%$ of the lizards sighted were under vegetation is also associated to thermoregulation. They look for milder temperatures during the warmer periods of the day, thus avoiding overheating. As was observed in a study carried out by BuJES \& VERRASTRo (2006) the mean temperature of the substrate was $29.59^{\circ} \mathrm{C}$. The substrate corresponds to the place where the lizards were captured, close to the bushes. Moreover, this behavior leads to predator escape and capture of prey that live among the vegetation. RocHA (1988) observed the same activity pattern for, L. lutzae where the activity concentration during the morning would be associated to the increase of substrate temperature late morning (11h). Moreover, this behavior helps them both to evade predators and to capture preys found under the vegetation. Verrastro \& BujEs (1998), studying the same species during the months of January and February (when temperatures are the highest in the area of dunes), observed that the main activity for that period of the year was found under vegetation, Liolaemus occipitalis presents a omnivore diet (VERRASTRO, 2004), which according to RocHA (1992), would represent an alternative to compensate the impossibility of the lizards to graze for a long period of time, when temperatures are critical. Substrate temperatures limit the activities of the lizards during the warmest hours of the day, when they are confined to shadows under the grassy vegetation. In

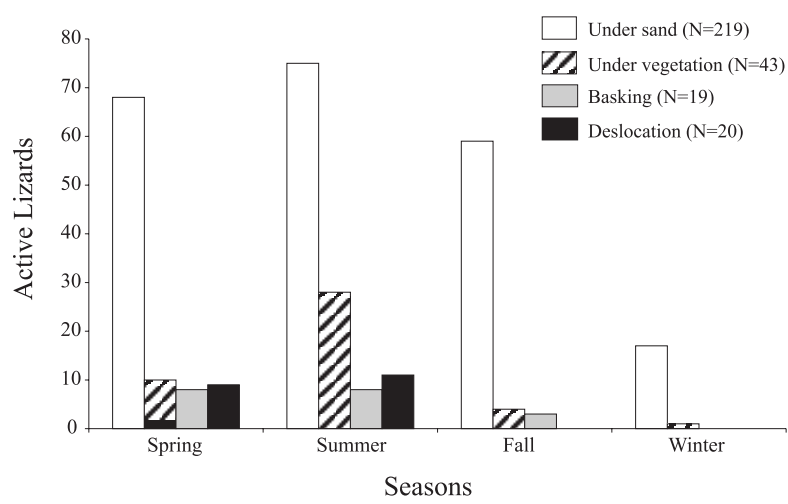

Fig. 2. Distribution of Liolaemus occipitalis Boulenger, 1885 in the sand dunes of Quintão beach, Palmares do Sul, southern Brazil, recorded by activity on each season $(\mathrm{N}=270)$ between September 1998 and August 1999. 
these periods of the day, the access to vegetal material would be a way to ingest food without the exposure to high temperatures of the hot substrate. Lizards were seen changing places from one tuft to another (7\%), that could be associated to the presence of the observer. Only $6 \%$ of the sighted lizards were in the sun, a thermoregulatory behavior that puts the lizard under solar radiation and its body in direct contact with the heated substratum (Fig. 2). As documented for other lizards from open areas, this behavior is not well observed for L. lutzae (RocHA, 1995). According to the author, this fact would be associated to predation risk and exposure to high substrate temperatures that occur far from the vegetation. This behavior was occasionaly observed in L. lutzae, especially early in the morning (RocHA, 1995).

There was always one age group absent for every season (Fig. 3): juvenile lizards during spring, immature females during summer, and adult females during fall and winter, once a time this species reaches sexual maturity in their first reproductive season after birth (VERRASTRO $\&$ Krause, 1994). Adult males were the only group found active throughout the year, maybe due to the matter of the species territoriality. The frequency of these groups in their different activities per season varied along the year. The most frequent activity during Spring was under sand (digging), representing $81.2 \%$ of the activity of immature females, $93.3 \%$ of immature males, $70.3 \%$ of adult females, and $55.5 \%$ of adult males. Other activities were also registered for both adult males and females during Spring, consisting of dislocation $(16.2 \%$ females and $11.1 \%$ males); under vegetation (5.4\% females and $22.2 \%$ males); and basking (8.2\% females and $11.1 \%$ males). During the summer, the number of observed young specimens was very low, with the population represented mainly by adults. The most frequent activity was under sand, representing $56.7 \%$ of females activity and $65.2 \%$ of males. The activities under vegetation represented $25.4 \%$ and $23.9 \%$ for females and males, respectively; dislocation was less frequent, $10.4 \%$ and $8.7 \%$ for females and males, respectively; and basking, $7.5 \%$ and $2.8 \%$ for females and males, respectively. During fall and winter, the observations consisted almost only of young specimens, being under sand the most frequent activity (89.1\%).

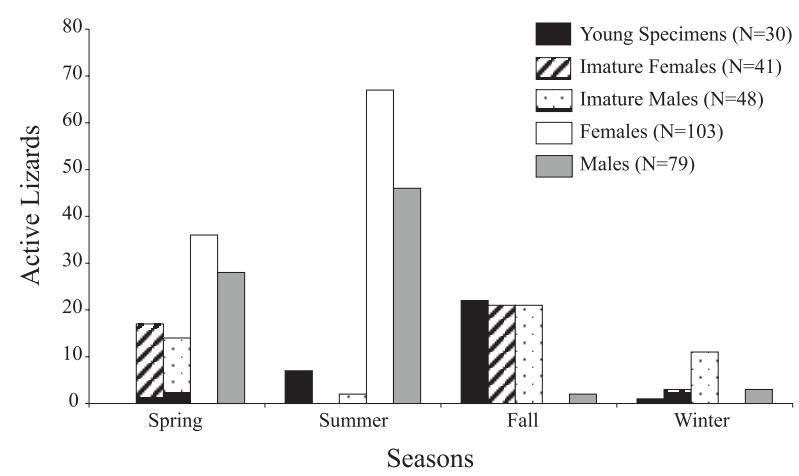

Fig. 3. Distribution of Liolaemus occipitalis Boulenger, 1885 in the sand dunes of Quintão beach, Palmares do Sul, southern Brazil, recorded by age classes on four seasons $(\mathrm{N}=270)$ between September 1998 and August 1999.
We concluded that Liolaemus occipitalis is a thigmothermic and heliothermic species; its major activity, as registered through the observations made for the present study, was superficial diving into the sand. The lizard is active all throughout the year, and its activity is directly related to thermal changes in the environment. It uses its microhabitat mainly as a means for thermoregulating, evading predators, and ambushing preys.

Acknowledgements. Technical and administrative support were provided by the Post-Graduation Program in Zoology, Pontifícia Universidade Católica do Rio Grande do Sul and by the Herpetology Sector, Department of Zoology, Universidade Federal do Rio Grande do Sul. We also acknowledge Dr. Thales de Lema, advisor during this work; to Rodrigo Caruccio, Carolina Castilhos, Marina Picolli and Janaína Bujes, for helping in fieldwork. Financial support was provided by CAPES.

\section{REFERENCES}

Bujes, C. S. \& Verrastro, L. 2006. Thermal biology of Liolaemus occipitalis (Squamata, Tropiduridae) in the coastal sand dunes of Rio Grande do Sul, Brazil. Brazilian Journal of Biology 66(3):29-41.

Delaney, P. J. V. 1965. Fisiografia e geologia da superfície da planície costeira do Rio Grande do Sul. Publicação Especial Escola de Geologia da UFRGS 6:1-105.

EIDT, R. C. 1968. The climatology of South America. In: FitKaU, E. J.; Illies, J.; Linge, H.; Schwabe, G. H. \& Sioli, H. eds. Biogeography and Ecology in South America. The Hague, Dr. W. Junk N. V. p.54-81.

Fuentes, E. R. \& JAKsiC, F. M. 1979. Activity temperatures of eight Liolaemus (Iguanidae) species in Central Chile. Copeia 1979:546-548.

Gibbons, J. R. H. \& Lillywhite, H. B. 1981. Ecological segregation, color matching, and speciation in lizard of the Amphibolurus decresii complex. (Lacertilia, Agamidae). Ecology 62:15731584.

Grant, B. W. 1990. Trade-offs in activity time and physiological performance for thermoregulating desert lizards, Sceloporus merriami. Ecology 71:2323-2333.

Grant, B. W. \& Dunham, A. E. 1988. Thermally imposed time constraints on the activity of the desert lizard Sceloporus merriami. Ecology 69:167-176.

Grover, M. C. 1996. Microhabitat use and thermal ecology of two narrowly sympatric Sceloporus (Phrynosomatidae) lizards. Journal of Herpetology 30(2):152-160.

Halloy, M.; Etheridge, R. \& Burfhardt, G. M. 1998. To bury in sand: phylogenetic relationships among lizard species of the boulengeri group, Liolaemus (Reptilia: Squamata: Tropiduridae), based on behavioral characters. Herpetological Monographs 12:1-37.

Heath, J. E. 1970. Behavioral regulation of body temperature in poikilotherms. Physiologist 13:399-410.

Marcellini, D. \& Mackey, J. P. 1970. Habitat preferences of the lizards Sceloporus occidentalis and S. graciosus (Lacertilia: Iguanidae). Herpetologica 26:51-56.

NúñEZ, H. 1996. Autoecología comparada de dos especies de lagartijas de Chile central. Publicación Ocasional del Museo Nacional de Historia Natural de Chile 50:5-60.

Núñez, H.; Marquet, P. A.; Medel, R. G. \& Jaksic, F. M. 1989. Niche relationships between two sympatric Liolaemus lizards in a fluctuating environment: the "lean" versus "feast" scenario. Journal of Herpetology 23:22-28.

Pfadenhauer, Von, J. 1980. Die vegetation der küstendünen von Rio Grande do Sul Südbrasilien. Phytocoenologia 8(3/4):321-364.

Pfadenhauer, Von, J. \& Ramos, F. R. 1979. Um complexo de vegetação entre dunas e pântanos próximo a Tramandaí, Rio Grande do Sul, Brasil. Iheringia, Série Botânica, 25:17-26.

Pianka, E. R. 1977. Reptilian species diversity. In: Gans, C. \& Tinkle, D. W. eds. Biology of Reptilia, New York, Academic. p. $1-34$. 
Porto, R. P. \& Cortazzi, A. M. 1982. Carta de solos do Rio Grande do Sul. Mapas temáticos do Rio Grande do Sul. Porto Alegre, Secretaria de Agricultura.

Rocha, C. F. D. 1988. Ritmo de atividade e microclimatologia do habitat de Liolaemus lutzae (Sáuria: Iguanidae). Anais Seminário Regional de Ecologia. São Carlos, VI:269-281. 1991. Composição do habitat e uso do espaço por Liolaemus lutzae (Sauria: Tropiduridae) em uma área de restinga. Revista Brasileira de Biologia 51(4):339-346.

1992. Reproductive and fat body cycles of the tropical sand lizard (Liolaemus lutzae) of Southeastern Brazil. Journal of Herpetology 26(1):17-23.

1995. Ecologia termal de Liolaemus lutzae (Sauria: Tropiduridae) em uma área de restinga do sudeste do Brasil. Revista Brasileira de Biologia 55(3):481-489.

Roughgarden, J. D.; Heckel, D. \& Fuentes, E. R. 1983. Coevolutionary theory and biogeography and community structure of Anolis. In: Huey, B.; Pianka, E. R. \& Schoener, T. W. eds. Lizard Ecology: studies of a model organism. Cambridge, Harvard University. p.371-410.

SAlzburg, M. A. 1984. Anolis sagrei and Anolis cristatellus in southern Florida: a case study in interspecific competition. Ecology 65:14-19.
Scheibe, J. S. 1987. Climate, competition, and the structure of temperate zone lizard communities. Ecology 68:1424-1436

Schoener, T. W. 1977. Competition and the niche. In: Gans, C. \& TinkLE, D. W. eds. Biology of Reptilia. New York, Academic Press. v.7. p. 35-136.

Verrastro, L. 2004. Sexual dimorphism in the lizard Liolaemus occipitalis (Iguania-Tropiduridae). Iheringia, Série Zoologia, 94(1):45-48.

Verrastro, L. \& Bujes, C. S. 1998. Ritmo de atividade de Liolaemus occipitalis Boulenger, 1885 (Sauria, Tropiduridae) na Praia de Quintão, RS - Brasil. Revista Brasileira de Zoologia 15(4):913-920.

Verrastro, L. \& Krause, L. 1994. Analysis of Growth in a Population of Liolaemus occipitalis Boul. 1885, from the Coastal Sand-dunes of Tramandai, RS, Brazil (Reptilia, Tropiduridae). Studies on Neotropical Fauna and Environment 29(2):99-111.

WAechter, J. L. 1985. Aspectos ecológicos da vegetação de restinga no Rio Grande do Sul, Brasil. Comunicações do Museu de Ciências PUCRS, Série Botânica, 33:49-68.

1990. Comunidades vegetais das Restingas do Rio Grande do Sul. ACIESP 3:228-248.

Recebido em maio de 2005. Aceito em outubro de 2007. ISSN 0073-4721

Artigo disponível em: www.scielo.br/isz 